\title{
Pharmacological characterization of the novel phosphodiesterase type 5 (PDE5) inhibitor lodenafil carbonate on human and rabbit corpus cavernosum
}

\author{
Gilberto De Nucci*, Raquel Lorenzetti, Cristina E Okuyama, \\ Juliana S Baracat, José L Donato, Edson Antunes and Cleber E Teixeira
}

Address: Department of Pharmacology, Faculty of Medical Sciences, UNICAMP, Campinas, SP, Brazil

Email: Gilberto De Nucci* - denucci@gdenucci.com

* Corresponding author

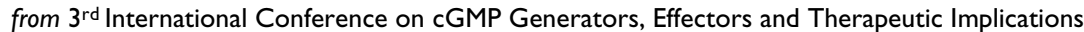

Dresden, Germany. I5-17 June 2007

Published: 25 July 2007

BMC Pharmacology 2007, 7(SuppI I):PI3 doi:I0.II86/I47I-22I0-7-SI-PI3

This abstract is available from: http://www.biomedcentral.com/I47I-22/0/7/SI/PI3

(c) 2007 De Nucci et al; licensee BioMed Central Ltd.

\section{Background}

Nitrergic nerves and endothelial cells release nitric oxide (NO) in the corpus cavernosum (CC), a key mediator that stimulates soluble guanylyl cyclase to increase cGMP levels and cause penile erection. Phosphodiesterase 5 (PDE5) inhibitors, such as sildenafil, prolong NO effects by inhibiting cGMP breakdown.

\section{Purpose}

We aimed to investigate the effects of the novel PDE5 inhibitor lodenafil carbonate (Fig. 1a) on in vitro cavernosal relaxation, mean arterial pressure, activity of crude PDE extracts from human platelets as well as to evaluate its pharmacokinetic properties.

\section{Methods}

In functional studies, cavernosal strips were mounted in organ baths for isometric force recording, coupled to a PowerLab 8/SP ${ }^{\mathrm{TM}}$ data acquisition system. Rats were surgically manipulated and telemetry transmitters were implanted in the abdominal aorta for measurements of systolic, diastolic and mean arterial blood pressure. For determination of PDE activity by LC-MS/MS analysis, lodenafilc arbonate $(0.005-1 \mu \mathrm{M})$ was preincubated in the enzymatic mixture for $5 \mathrm{~min}$ at room temperature. Reaction was initiated by the addition of the substrate cGMP $(5 \mu \mathrm{M})$ at $35^{\circ} \mathrm{C}$ for $30 \mathrm{~min}$. Pharmacokinetics was studied by tandem mass spectrometry (LC-MS/MS) with positive ion electrospray ionization using multiple reactions monitoring (NMR) method. Blood samples were collected at 0.02 to $24 \mathrm{~h}$ after drug administration by intravenous (1 mg/kg) and oral $(10 \mathrm{mg})$ routes. The hydrolysis of lodenafil carbonate (final concentration 10 $\mu \mathrm{M}$ ) was also studied in human, dog and rat plasma as well as in acid solution (100 $\mathrm{mM}$ hydrochloric acid).

\section{Results}

The cumulative addition (0.001-100 $\mu \mathrm{M}$ ) lodenafil carbonate to the bathing medium produced concentrationdependent relaxations in phenylephrine-precontracted $\mathrm{CC}$ with $\mathrm{pEC}_{50}$ values of $6.55 \pm 0.02$ and $5.97 \pm 0.07$ in rabbit and human tissues, respectively (Fig. 1b). The addition of lodenafil carbonate $(0.1 \mu \mathrm{M})$ caused significant leftward shifts in the concentration-response curves to acetylcholine $(0.01-100 \mu \mathrm{M})$ in rabbit and human corpus cavernosum, along with and enhancement of maximal responses. The addition of lodenafil carbonate significantly potentiated both the magnitude and the duration of electrically-evoked relaxant responses (1-20 Hz) in human and rabbit penile tissue. Treatment with lodenafil carbonate (1-10 mg/kg) caused neither dose- nor timedependent changes in the mean arterial blood pressure $(123 \pm 6 \mathrm{mmHg}$ to $132 \pm 7$ among the different doses and times selected for measurements). Lodenafil carbonate 

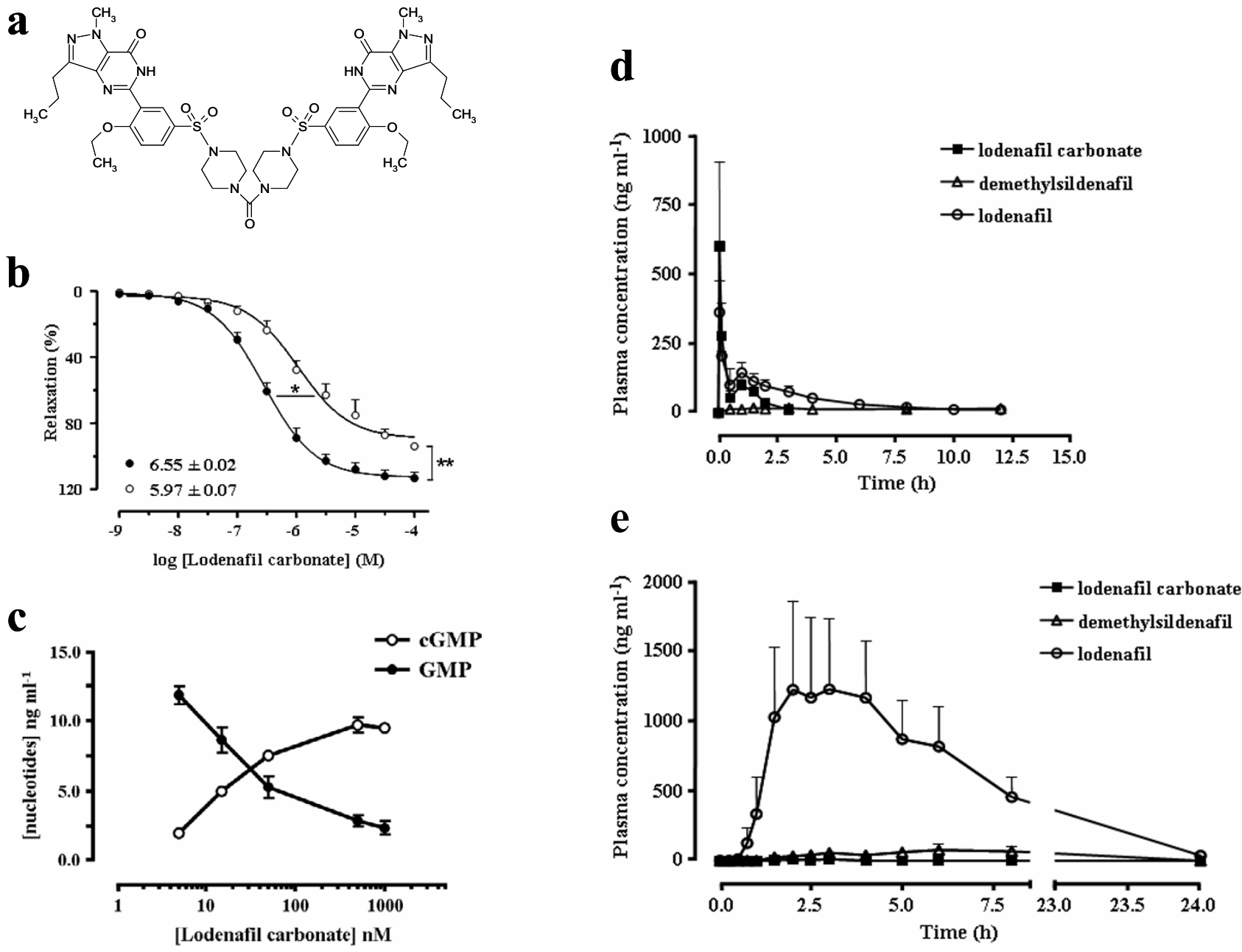

Figure I

(a) Structure of lodenafil carbonate; (b) Concentration-response curves to lodenafil carbonate $(0.001-100 \mu \mathrm{M})$ in rabbit (closed circles) and human (open circles) CC; (c) Effect of lodenafil carbonate on cyclic GMP hydrolysis; (d, e) Mean plasma concentrations of lodenafil carbonate, lodenafil and demethylsildenafil in Beagle dogs after single intravenous (I mg/kg; top) and oral ( $10 \mathrm{mg}$; bottom) doses of lodenafil carbonate.

reduced cGMP hydrolytic activity as a function of increasing inhibitor concentration, with $\mathrm{IC}_{50}$ value approximately 2-fold lower than sildenafil at the substrate concentration used $(5 \mu \mathrm{M})$ (Fig. 1c). Following a single i.v. dose of lodenafil carbonate $(1 \mathrm{mg} / \mathrm{kg})$ to male Beagle dogs, the compound exhibited $\mathrm{C}_{\max }$ of $599 \mathrm{ng} / \mathrm{ml}$ and high plasma clearance of $3.24 \mathrm{l} / \mathrm{h} / \mathrm{kg}$ with a volume of distribution of $2.73 \mathrm{l} / \mathrm{kg}$. This volume of distribution resulted in the elimination half-life value of $0.57 \mathrm{~h}$ (Fig. 1d). Plasma concentrations of lodenafil carbonate after a single oral dose $\left(10 \mathrm{mg}\right.$ ) achieved a $\mathrm{C}_{\max }$ of $11 \mathrm{ng} / \mathrm{ml}$ (Fig. 1e). However, the $\mathrm{C}_{\max }$ for lodenafil was $1357 \mathrm{ng} / \mathrm{ml}$ and $\mathrm{T}_{\max }$ was approximately $2 \mathrm{~h}$, reflecting the occurrence of systemic metabolism. The half-life of lodenafil carbonate after p.o. administration $(2.11 \mathrm{~h})$ was slightly longer than the equivalent value after i.v. dosing, suggesting that the rate of absorption limited the overall rate of elimination. In the study of the stability of lodenafil carbonate $(1 \mu \mathrm{M})$ in acid solution, the employment of HPLC and mass spectral analysis of the $2 \mathrm{~h}$ incubations revealed the presence of lodenafil and lodenafil carbonate as the major components detected. The retention times obtained for sildenafil, lodenafil, lodenafil carbonate and demethylsildenafil were $4.00,2.51,7.43$ and $2.04 \mathrm{~min}$, respectively. In human and dog plasma, a similar qualitatively pattern was observed, with lodenafil carbonate being detected in higher levels than lodenafil. No trace of demethylsildenafil was detected in both acid and plasma stability assays.

\section{Conclusion}

Lodenafil carbonate compound, which concentrationdependently inhibits cGMP-dependent PDE hydrolytic 
activity, relaxes human and rabbit cavernosal tissue and enhance endogenous NO-induced responses. Advances in treatment of erectile dysfunction seem likely in the immediate future and lodenafil carbonate represents an attractive agent in that regard, based on the findings provided in the present investigation.

Publish with Bio Med Central and every scientist can read your work free of charge

"BioMed Central will be the most significant development for disseminating the results of biomedical research in our lifetime. " Sir Paul Nurse, Cancer Research UK

Your research papers will be:

- available free of charge to the entire biomedical community

- peer reviewed and published immediately upon acceptance

- cited in PubMed and archived on PubMed Central

- yours - you keep the copyright

Submit your manuscript here:

http://www.biomedcentral.com/info/publishing_adv.asp 